\title{
WSPÓŁCZESNEJ SOCJOLOGII WSI PORTRET WŁASNY. REFLEKSJE W ŚWIETLE DWÓCH PODRĘCZNIKÓW ${ }^{1}$
}

\begin{abstract}
Abstrakt. W rozważaniach podjęta jest refleksja nad obszarami i sposobami badań w zakresie socjologii wsi, prezentowanymi w dwóch ostatnio opublikowanych podręcznikach z tego zakresu. Obydwa, chociaż mają ambicje odniesienia do globalnych zjawisk i problemów, tak naprawdę skupiają się na zagadnieniach dotyczących obszarów tzw. Globalnej Północy, z niewielkimi wyjątkami dotyczącymi Europy Wschodniej i Ameryki Łacińskiej. Zasadnicze jednak różnice między obydwoma podręcznikami są dwie. O ile w pierwszym (z roku 2006) ważna jest kwestia perspektyw analityczno-teoretycznych (tzw. teoretycznych koordynatów), o tyle w drugim (z roku 2016) istotniejsze są zagadnienia dotyczące rozmaitych bardziej szczegółowych kwestii, którym poświęcono odpowiednie fragmenty analiz. Ponadto w pierwszym opracowaniu brakuje wyraźnego wstępu i zakończenia, co świadczyć może o większej autonomii poszczególnych podejmowanych w analizach kwestii. Natomiast w opracowaniu drugim obszerna ilość szczegółowych analiz wymusza sformułowanie jakichś ogólniejszych uwag ze strony redaktorów tomu. Różnice między nimi świadczą o tym, że w ciągu 10 lat socjologia wsi (czy raczej studiów nad obszarami wiejskimi) doświadczyła efektów inter- i transdyscyplinarności, co spowodowało wymieszanie rozmaitych wątków i perspektyw analiz, które nie dają się łatwo wyodrębnić w bardziej autonomiczne perspektywy analizy obszarów wiejskich.
\end{abstract}

Słowa kluczowe: socjologia wsi, obszary wiejskie, podręczniki, Globalna Północ, interdyscyplinarność - transdyscyplinarność.

\section{Wprowadzenie}

Niniejsze opracowanie jest esejem powstałym w oparciu o lekturę dwóch bardzo obszernych międzynarodowych tomów poświęconych socjologii wsi jako swoistej subdyscyplinie naukowej (Cloke, Marsden, Mooney 2006; Shucksmith, Brown 2016). Moim zamierzeniem jest syntetyczne zaprezentowanie zawartości tych opracowań w celu ukazania dwóch kwestii: (1) jakie zagadnienia są

* Prof. dr hab., Instytut Socjologii, Uniwersytet Jagielloński, ul. Grodzka 52, 31-044 Kraków, e-mail:kgorlach@interia.pl

${ }^{1}$ Tekst niniejszy dedykuję moim Przyjaciołom - Elżbiecie Psyk-Piotrowskiej, Andrzejowi Pilichowskiemu i Andrzejowi Majerowi z okazji Ich jubileuszu. 
dzisiaj podejmowane przez badaczy identyfikujących się jako „socjologowie wsi” (rural sociologists)?; (2) jakie koncepcje analityczne i teoretyczne są przywoływane dzisiaj po to, aby badać problematykę obszarów wiejskich? Warto jednak nadmienić, że obydwa opracowania pojęcie „socjologia wsi” (rural sociology) zastąpiły pojęciem „studia nad obszarami wiejskimi” (rural studies). Można na tej podstawie stwierdzić, że redaktorzy obydwu tomów stoją na stanowisku, że do analiz problemów związanych ze wsią konieczne jest zastosowanie raczej wielodyscyplinarnego podejścia aniżeli koncentrowanie się na perspektywie socjologicznej. Co więcej, należy zaznaczyć, że drugie ze wskazanych opracowań podkreśla w swoim tytule międzynarodowy (international) charakter. W swych rozważaniach zwrócę zatem szczególną uwagę na tę kwestię, która powinna różnić obydwa tomy.

\section{Handbook of Rural Studies ${ }^{2}$}

Opracowanie zbiorowe (por. Cloke, Marsden, Money, 2006) zawiera 35 artykułów, głównie autorskich opracowań, jako że tylko pięć jest efektem pracy zbiorowej dwojga lub nawet trojga autorów/autorek. Ten obfity zestaw materiałów został podzielony na trzy zasadnicze części, z których pierwsza i trzecia (ostatnia) nie zostały podzielone na mniejsze fragmenty. Pierwsza część nosi tytuł „Podejścia do analiz obszarów wiejskich”, zaś trzecia zatytułowana jest „Nowe wiejskie relacje". Tylko część środkowa (druga), skupiona na perspektywach teoretycznych (theoretical coordinates), z racji swojej obszerności podzielona została na osiem części, dotyczących odpowiednio: kulturowych reprezentacji wiejskości; przyrody; zrównoważenia; nowych gospodarek; kwestii władzy; nowego konsumeryzmu; tożsamości oraz wykluczenia.

W części wstępnej do omawianego tomu (podejścia do analiz obszarów wiejskich) zamieszczonych jest siedem analiz dotyczących zasadniczych sposobów ujęcia problematyki wsi. Część tę rozpoczyna Terry Marsden, podejmując rozważania wokół rozmaitych ścieżek socjologicznego ujęcia wiedzy na temat wsi. Wiedza ta - jego zdaniem - nabiera obecnie cech teoretycznej dojrzałości, integrując w swoim obrębie problematykę ryzyka, dotyczącego np. rozmaitych regulacji odnośnie do produkcji żywności, jak i kwestie związane z kształtowaniem się nowych tożsamości regionów i społeczności lokalnych. Oznacza to obecność wielu różnych wątków i tradycji konceptualizacyjnych i teoretycznych w obrębie analiz obszarów wiejskich. Z kolei Paul Cloke wprowadza do tych rozważań

2 Ten fragment rozważań jest nieco zmienioną wersją części mojego artykułu pt. Kierunki badań wsi w spoteczeństwie globalnej ponowoczesności, czyli od „nowej” socjologii wsi do studiów nad wsia ponowoczesna, zamieszczonego w książce pod redakcją Marii Halamskiej, Wieś jako przedmiot badań naukowych na początku XXI wieku, Wydawnictwo Naukowe SCHOLAR, Warszawa 2011, s. 139-168. 
wątek różnych sposobów konceptualizowania wiejskości jako takiej. Autor ten wskazuje w tym kontekście na trzy znaczące - jak to określa - ramy teoretyczne, które obejmują: (1) ujęcie funkcjonalne (zwrócenie uwagi na dominację gospodarki rolnej i leśnej; mniejsze demograficzne zagęszczenie; bardziej spójna tożsamość mieszkańców, wynikająca przede wszystkim z bardziej jednolitego charakteru środowiska zamieszkania); (2) ujęcie o charakterze ekonomiczno-politycznym (obszar ekonomii politycznej), zwracające uwagę na specyficzne formy reprodukcji warunków społecznych i ekonomicznych zachodzące na obszarach wiejskich; (3) ujęcie z perspektywy społecznej konstrukcji, które wiąże je z rozmaitymi wyobrażeniami na temat wiejskości wynikającymi z kulturowych i społeczno-przestrzennych charakterystyk. W tych też kontekstach rozważana jest możliwość tworzenia specyficznej teorii „,wiejskości”. W następnym rozdziale trójka socjologów australijskich (Stewart Lockie, Geoffrey Lawrence i Lynda Cheshire) poddaje analizie szczególny aspekt wiejskości, jakim jest zarządzanie, a w zasadzie współrządzenie (governance) naturalnymi zasobami. Analiza tych zagadnień prowadzi autorów także do identyfikacji rozmaitych zagrożeń, które mogą podawać w wątpliwość reguły i zasady rozwoju zrównoważonego. Wątki różnych sposobów konceptualizowania „wiejskości” kontynuuje w swoich rozważaniach Keith Halfacree, skupiając się na zagadnieniach konstrukcji wiejskiej przestrzeni (rural space). Jego zdaniem należy posługiwać się niejako trójkątnym modelem takiej przestrzeni, biorąc jednocześnie pod uwagę takie komponenty, jak: specyficzne lokalności (miejsca) wyznaczone określonymi typami praktyk produkcyjnych czy konsumpcyjnych; formalne reprezentacje wiejskości w systemie kapitalistycznych interesów oraz biurokratycznych regulacji; codzienne sposoby życia „wiejskich całości”, które są z reguły niespójne i zróżnicowane i uwzględniają także indywidualne i społeczne (kultura) elementy uwikłane w procesy poznawczych interpretacji i negocjacji. Kolejny sposób analizy wiejskości prezentuje Ruth Panelli, próbując przybliżyć pojęcie społeczeństwa wiejskiego (rural society). W swoich rozważaniach autorka dokonuje przeglądu różnych perspektyw analitycznych (pozytywistyczna, hermeneutyczna, marksistowska, feministyczna, postmodernistyczna) w odniesieniu do różnych elementów wiejskości (rodzina, społeczność, lokalność) oraz zachodzących procesów, dotyczących takich kwestii, jak: zróżnicowanie społeczne, klasa, gender, władza, zasoby, relacje społeczne, nierówności. Rozważania w tym obszarze zostają uzupełnione przez analizy dotyczące sfery gospodarki powiązanej z obszarami wiejskimi. Autorzy tego fragmentu rozważań, czyli Matteo B. Marini oraz Patrick H. Mooney wskazują na wykształcenie się na obszarach wiejskich przynajmniej trzech typów gospodarki. Określone one zostają przez nich jako: gospodarka uzależniona od eksploatacji naturalnych zasobów (rent-seeking economy), gospodarka uzależniona od środków zewnętrznych (dependent economy) oraz gospodarka przedsiębiorcza (entrepreneurial economy). Tylko ta ostatnia bazuje na inicjatywie, która jest w stanie zapewnić jakieś elementy rozwoju zrównoważonego, 
wykorzystując z jednej strony lokalne zasoby, z drugiej zaś - ponadlokalne środki. Rozważania te uzupełniają analizy dotyczące polityki odnośnie do obszarów wiejskich oraz planowania ich rozwoju. W tym przypadku Mark B. Lapping zwraca uwagę na fakt, że w tym względzie należy wziąć pod uwagę jednocześnie rozmaite perspektywy postrzegania problemów wiejskich, takie jak np. perspektywa regionalna, uwzględnianie efektów ekonomii skali, zależność od fizycznej infrastruktury badanych obszarów, duże projekty dotyczące tworzenia miejsc pracy oraz ruchliwości kapitału i siły roboczej, kwestie interesów miejscowej ludności oraz ochrony środowiska i usprawniania systemów zarządzania.

$\mathrm{W}$ prezentowanym tomie zawarte są też cztery prezentacje dotyczące zagadnień nowych relacji społecznych zachodzących na obszarach wiejskich. Pierwsza z nich dotyczy wiejskości oraz odmienności (inności). Autor, Paul Cloke, zwraca tutaj uwagę na potrzebę i jednocześnie trudności związane z ujmowaniem w kontekście wiejskim osób doświadczających problemów mentalnych. W nieco innym kontekście omawiane jest też doświadczenie przeżywania dzieciństwa na wsi, jak również poczucie lęków i obaw wyrażanych przez mieszkańców wsi w obliczu pojawiania się obcych. Innym wymiarem owego doświadczania odmienności jest obecność np. rozmaitych gatunków zwierząt, które stają się niejako konstytutywnymi elementami dla określenia swoistości obszarów wiejskich także poprzez ich relacje w odniesieniu do ludzi. W innym rozdziale Michael Woods prezentuje zagadnienia związane $\mathrm{z}$ artykulacją polityczną interesów i wyznawanych wartości mieszkańców wsi, czy też szerzej, osób pojawiających się na obszarach wiejskich. Stwarza to szanse na wykorzystanie rozmaitych koncepcji teoretycznych, takich jak np. koncepcja obywatelstwa, koncepcja tożsamości, czy koncepcje mobilizacji społecznej. Analizy prowadzone w tym zakresie mogą zatem dotyczyć zagadnień współrządzenia, aktywności obywatelskiej, obecności usług publicznych na obszarach i w społecznościach wiejskich oraz strategii ich ekonomicznego rozwoju i odnowienia czy odtworzenia (regeneracji) więzi społecznych. W tym też kontekście Eduardo Sevilla Guzman i Joan Martinez-Alier skupiają się na szczególnej problematyce nowych ruchów społecznych oraz agroekologii. Rozważania tej dwójki autorów mają w gruncie rzeczy charakter bardzo ogólnych analiz podjętych w kontekście bardzo określonych wydarzeń zachodzących na kontynencie latynoamerykańskim. Chodzi o rozmaite ruchy mające swe korzenie na obszarach wiejskich, które mogą być traktowane jako formy protestu neoliberalnej globalizacji. Wreszcie w ostatnim rozdziale składającym się na tę część prezentowanego tomu Tim Edensor przedstawia rozważania dotyczące konwencji i zachowań (performances) podejmowanych przez mieszkańców wsi oraz osoby przebywające na obszarach wiejskich. Podkreśla szczególnie coraz wyraźniej obserwowaną różnorodność dopuszczalnych form zachowań na wsi oraz pojawiające się w tym kontekście konflikty, jak np. te dotyczące tradycyjnych polowań na lisy w Wielkiej Brytanii. 
W prezentowanym opracowaniu zwraca jednak uwagę przede wszystkim ta jego część, która wskazuje na zasadnicze kierunki badań wsi, u podstaw których leżą - jak to określają autorzy - teoretyczne koordynaty (coordinates). Są to $\mathrm{w}$ gruncie rzeczy pewne osie problemowe, niosące jednak w sobie właśnie ładunek teoretyczny, stanowiące zasadnicze - jeśli można to tak określić - punkty orientacyjne debaty na temat najbardziej istotnych zagadnień badania wsi we współczesnych wysokorozwiniętych społeczeństwach. Egzemplifikacjami empirycznymi tych ostatnich są w tej pracy przede wszystkim społeczeństwa brytyjskie i amerykańskie, w mniejszym stopniu australijskie, a już zupełnie sporadycznie także inne, np. francuskie. Autorzy wskazują osiem takich teoretycznych punktów orientacyjnych. Są to kolejno: reprezentacje kulturowe; przyroda (natura); zrównoważenie (rozwój zrównoważony); nowe gospodarki; władza; nowy konsumeryzm; tożsamość oraz wykluczenie. Każdemu wyznaczonemu przez te osie typowi problematyki poświęcone zostały trzy opracowania, będące niejako rozwinięciem wskazanych zagadnień i identyfikacji określonych problemów badawczych.

Kulturowe reprezentacje stanowią współcześnie - zdaniem autorów - fundamentalny obszar badań wiejskich. Uwikłany jest w to z jednej strony tradycyjny dualizm przyrody (tego co naturalne, dzikie) i kultury (czyli tego, co jest efektem kreacji człowieka); z drugiej zaś przeświadczenie, że sam obraz natury, a w tym i wsi, która traktowana jest jako swoisty przejaw natury, czy coś znajdującego się pośrodku między dziką naturą a cywilizacją miasta, jest efektem społecznej kreacji, powodowanej rozmaitymi pożądaniami. Owo pożądanie może być niejednokrotnie wyrazem tęsknoty za romantycznym ideałem, z jakim kojarzona jest natura. Melanie DuPuis odwołuje się tutaj przede wszystkim do przykładów właściwych dla społeczeństwa angielskiego, gdzie w dyskursie publicznym wyobrażenia na temat wsi uzyskują rangę swoistego simulacrum, stanowiącego potwierdzenie większej wagi świata wyobrażeń aniżeli świata realnego. Rodzi to jednak - zdaniem autorki - niebezpieczeństwo niewłaściwego, czy też zbyt jednostronnego, ujęcia obszaru wiejskiego i wyobrażeń na jego temat. Chcąc uchwycić wieloaspektową rzeczywistość wsi, musimy wyrzec się właśnie odwołań do owego romantycznego, idyllicznego pożądania, operującego dualizmem: natura - kultura, postęp - regres, prawda - fałsz, natomiast skupić się na innym rodzaju narracji, jakim są ,zakorzenione wiedze” (situated knowledges), czyli swoiste określone orientacje, dotyczące różnych aspektów wiejskiej rzeczywistości.

W kontekście kulturowych reprezentacji wsi szczególnie istotna jest, wspomniana wyżej, rola wiejskiej idylli, czyli traktowania wsi jako swoistego „raju utraconego", którego choćby namiastkę należałoby być może przywrócić. Problem jednak w tym, że sama idylla i to, co się pod nią kryje, są przedmiotem sporów i kontrowersji. Jak podkreśla Brian Short, najbardziej istotny wydaje się tutaj kulturowy wymiar idylli, ten odnoszący się do harmonii, stałości, bezpieczeństwa, swoistej wewnętrznej siły, odświeżenia i odnowy. Sam charakter idylli ulega historycznym zmianom. W szczególności procesy modernizacji, a przede 
wszystkim industrializacja i urbanizacja, wpłynęły na obraz wiejskiej idylli jako przeciwstawienia negatywnych cech uosabianych przez miasto i nowoczesność. Istotne jest jednak przede wszystkim to, że idylla wiejska to przecież typowy konstrukt społeczny, to pewne wyobrażenie wsi i jej krajobrazu z silnymi elementami wartościującymi. Na pytanie, gdzie faktycznie można odnaleźć wiejską idyllę, David Bell przekornie odpowiada, że miejscem, gdzie można odnaleźć idyllę wiejską, jest miasto, bo przecież tam została ona wytworzona. Idylle, z uwagi na to, że tworzone są przez różnych aktorów społecznych oraz z rozmaitych powodów, są ponadto różnorodne. Współcześnie idylla wiejska nabiera globalnego charakteru. Tworzona jest $\mathrm{w}$ mediach, w ruchu turystycznym, w procesach konsumowania, spożywaniu żywności, przede wszystkim tej „regionalnej” czy „ekologicznej”. W powodzi rozmaitych odmian idylli można wyróżnić - zdaniem Bella - trzy jej typy idealne, tj.: idyllę rolniczą, idyllę dzikości oraz idyllę sportu, zabawy, rekreacji czy odpoczynku. W tej perspektywie obszary wiejskie jawią się jako coś pozytywnego. Możliwe są jednak wyobrażenia o wsi jako czymś „okropnym", czyli swoiste kontridylle. Osobnym problemem jest zderzenie idylli - czy wyobrażeń na temat wsi tworzonych przez media czy przedsiębiorstwa zajmujące się turystyką - z wiedzą i wyobrażeniami ludzi, którzy bezpośrednio stykają się ze wsią i jej problemami. Krótko mówiąc, problem idylli wiejskiej współcześnie to bardzo złożony dyskurs, zawierający wiele różnorodnych wątków i wciągający wielu różnych aktorów społecznych.

Kolejna oś analiz współczesnych studiów dotyczących wsi ulokowana jest w obszarze natury, traktowanym tutaj jako wszelkie elementy nie-ludzkie, jako - zgodnie z obecną tendencją używania pojęć - aktorzy poza-ludzcy, działające podmioty. Koncepcje te odrzucają tradycyjną, przyjmowaną do tej pory zasadę separacji ontologicznej pomiędzy światem ludzkim i pozaludzkim oraz normatywne wyjaśnienia tego dualizmu. Zgodnie z ideą zawartą w nowszych koncepcjach konstrukcjonistycznych (np. teoria Aktora-Sieci czy koncepcje nie-reprezentacyjne), skupione są one przede wszystkim na uwarunkowaniach istnienia wszystkich organizmów tworzących wiejski świat. Tradycyjny konstrukcjonizm społeczny jest we współczesnych studiach nad wsią odrzucany przede wszystkim z uwagi na traktowanie analizowanych bytów jako statycznych, podczas gdy one charakteryzują się dynamicznym i zmiennym charakterem. Współczesny konstrukcjonizm jest zróżnicowany. Można wyróżnić w nim trzy nurty: materialny (traktowanie przyrody jako domeny fizycznej); dyskursywny (zawierający idee, reprezentacje i obrazy przyrody) oraz materialno-semiotyczny (tworzący rozmaite schematy analityczne dotyczące materialności i dyskursu). W każdym jednak nurcie zawarta jest zasadnicza idea, wskazująca na to, że wiejska przyroda jest tworzona czy konstruowana jako domena fizyczna, jak również że wiejskość to określona kulturowa, konstruowana idea. W taki oto sposób następuje swoista de-naturalizacja natury. Staje się ona obiektem w pełni społecznym, jednak nie 
w sensie jakiejś „,realnej” społecznej rzeczywistości, ale raczej jako element swoistej „socjonaturalnej” relacyjnej koncepcji.

Przeświadczenie to demistyfikuje także uprzywilejowaną rolę aktorów ludzkich. Świat, w tym także i wieś, nie jest już tylko tworem ludzkim, ale raczej efektem relacji i oddziaływań pomiędzy różnymi podmiotami: ludźmi, żywymi organizmami nie-ludzkimi, technologią, kodami kulturowymi tworzącymi dyskurs, elementami przyrody nieożywionej, itp. W tym kontekście wskazywana jest np. teoria Aktora-Sieci (ANT), jako użyteczne, choć nie wolne od słabości, nowe teoretyczno-metodologiczne narzędzie analizy problematyki wsi. Niepełne ujęcie rzeczywistości wymusza zatem korektę tej perspektywy teoretyczno-metodologicznej, jaką oferuje ANT. Chodzi w niej przede wszystkim o wzmocnienie „hybrydalnego" ujęcia analizowanej rzeczywistości o bardziej precyzyjne ujęcie równowagi pomiędzy indywidualnością poszczególnych aktorów a relacyjnością, jako zasadniczą charakterystyką łączącej ich sieci. Służyć temu mają koncepcje współkonstytuowania (współkonstruowania) oraz umiejscowienia (dwelling) w odniesieniu do relacji pomiędzy dwoma zasadniczymi typami aktorów, tj. aktorami ludzkimi i nie-ludzkimi. Wzmacnia to przede wszystkim przeświadczenie o podmiotowości wszystkich aktorów, uczestników wiejskich (w tym przypadku) sieci. Przyjęcie takich teoretycznych rozstrzygnięć pozwala w nowy sposób spojrzeć np. na problematykę zwierząt, zarówno hodowlanych (stanowiących element produkcji rolnej), jak i dzikich (stanowiących element natury-wiejskości). Traktowane są one nie jako wytworzony towar, ale jako podmioty pełnoprawnie obecne w krajobrazie wiejskim, a badanie ich sytuacji to także analizy ich dobrostanu, komponentów kulturowych związanych ze stosunkiem do zwierząt, jak również z tym związanych problemów etycznych i współobecności z ludźmi w określonych fragmentach przestrzeni (miejscach).

Przyjęcie przez współczesną socjologię założenia o sieciowym charakterze współczesnego społeczeństwa wyznacza także spojrzenie na wieś jako coraz bardziej kompleksową całość. Ten kierunek i sposób badania wsi wyznaczony jest m.in. przez Jonathana Murdocha, który stwierdza, że obecne zmiany w życiu społecznym są rezultatem zastąpienia trwałych struktur społeczno-ekonomicznych problemami dynamicznych sieci. Sieci te to przede wszystkim przepływy różnych zasobów (kapitału, pieniędzy, towarów, siły roboczej, informacji oraz obrazów z różnych punktów pochodzenia do różnych punktów przeznaczenia, ulokowanych na poziomie globalnym, narodowym, regionalnym czy też lokalnym). Różnorodność sieci, zarówno z uwagi na tworzących je aktorów, jak i typy przepływów i relacji (także władzy), jakie zachodzą między nimi (istotny jest w tym ostatnim przypadku typ współrządzenia - governance), nie pozostaje bez wpływu na różnicowanie się dróg przemian poszczególnych regionów wiejskich. Stąd jednym z zasadniczych celów współczesnych studiów nad wsią staje się odzwierciedlenie tej wzrastającej różnorodności. Jednym z najważniejszych czynników, determinującym tę różnorodność, może być np. dominacja interesów 
określonych aktorów, którzy są w stanie kształtować określone obszary wiejskie zgodnie ze swoimi preferencjami.

Następna oś problemowa współczesnych studiów wiejskich to zrównoważenie. Chodzi mianowicie o szeroko rozumianą problematykę produkcji oraz kwestie związane z ochroną środowiska naturalnego. W sposób paradoksalny jednak nawiązanie do problematyki produkcji zrównoważonej powiązane jest $\mathrm{z}$ odejściem od traktowania wsi wyłącznie jako obszaru produkcyjnego. Wieś jest także obszarem konsumpcji. Koncepcja produkcji zrównoważonej i, co za tym idzie, zrównoważonego rozwoju obszarów wiejskich związana jest z koncepcją wsi post-produktywistycznej. Pojawiają się tutaj także inne idee, takie jak np. idea rozwoju alternatywnego, koncepcja „kontrruchów”, czyli działań skierowanych przeciwko standaryzacji produkcji żywności oraz globalnym łańcuchom żywnościowym, zdominowanym przez korporacje zajmujące się przetwórstwem i dystrybucją żywności. Istotą koncepcji zrównoważonej produkcji jest - zdaniem Terry'ego Marsdena - ponowne połączenie produkcji rolnej z szerszym społeczeństwem, zarówno wiejskim, jak i miejskim. Najogólniej rzecz ujmując, perspektywa rolnictwa zrównoważonego jest z jednej strony przeciwstawiana modelowi produkcji agro-industrialnej, z drugiej zaś - modelowi „biurokratyczno-higienicznego" rozwoju obszarów wiejskich, w ramach którego produkcja rolna ma zostać wypchnięta ze wsi w interesie tych grup, które dążą do wzmocnienia rezydencjalnych i rekreacyjnych funkcji wsi. Jak wspominałem wyżej, najbardziej istotnym elementem zrównoważonego systemu produkcji rolnej jest zapobieganie dewastacji środowiska naturalnego, czyli produkcja rolna spełniająca wymogi tzw. wartości agro-ekologicznych. Realizacja tej koncepcji możliwa jest - zdaniem Marsdena - przy uwzględnieniu rozmaitych elementów, pomijanych w modelu agro-industrialnym, takich jak: oparcie planów rozwojowych na społecznych i ekologicznych konwencjach, a nie technicznych rozwiązaniach i narzuconej regulacji, na kooperacji pomiędzy lokalnymi producentami i przetwórcami żywności, skoncentrowaniu się na jakości żywności traktowanej w sposób całościowy, nierozbitej na poszczególne parametry higieniczno-sanitarne; na wykorzystaniu wiedzy tradycyjnej, właściwej społecznościom lokalnym i grupom producentów, na kooperacji producentów i konsumentów.

Rozważania Marsdena, które zawierają jednak sporą dozę myślenia normatywnego, uzupełnione zostały w omawianej publikacji przez bardziej diagnostyczny wykład Fredericka H. Buttela. Nowoczesne rolnictwo jest - zdaniem tego autora - rolnictwem niezrównoważonym, przede wszystkim za sprawą trzech najbardziej istotnych charakterystyk. Należą do nich: specjalizacja produkcji - owocująca monokulturowymi obszarami produkcyjnymi obejmującymi nie tylko poszczególne wsie, ale także całe wiejskie regiony; intensyfikacja działań produkcyjnych - owocująca wzrastającą energochłonnością produkcji, użyciem zewnętrznych „wsadów” produkcyjnych, takich jak: środki chemiczne, systemy irygacyjne itp.; wreszcie przestrzenne oddzielenie produkcji roślinnej 
i zwierzęcej. Podtrzymywanie takiego systemu produkcji prowadzi do odtworzenia systemu rolnictwa niezrównoważonego, który przejawia się kolejno: powstaniem swoistej rolniczej techno-nauki, uniezależnieniem producentów od różnych regulacji dotyczących środowiska naturalnego, uzależnieniem od relatywnie niskich kosztów „wsadów” do produkcji, brakiem wpływu producentów (rolników) oraz członków społeczeństwa niezaangażowanych w produkcję rolną na koszty tej produkcji, globalną neoliberalizacją rolnictwa, czyli narzucaniem rozwiązań dotyczących tego działu produkcji całemu światu przez kraje wysokorozwinięte, charakteryzujące się właśnie niezrównoważonym modelem produkcji rolnej. Swoją diagnozę stanu światowego rolnictwa kończy Buttel szeregiem propozycji, które - jego zdaniem - powinny zostać spełnione, aby można było myśleć o zrealizowaniu przynajmniej pewnych elementów modelu zrównoważonego. W tym kontekście wskazuje on na: konieczność preferowania krótkich łańcuchów żywnościowych, czyli swoistą lokalizację produkcji rolnej i konsumpcji żywności, zmianę priorytetów badań dotyczących rolnictwa, surowe regulacje dotyczące środowiska i zasobów naturalnych, zmianę logiki do tej pory działającego mechanizmu rynkowego poprzez system eko-podatków, wreszcie położenie nacisku na wielofunkcyjność rolnictwa. Swoistym uzupełnieniem tych propozycji są rozważania innych autorów, dotyczące specyficznego elementu charakteryzującego obszary wiejskie, jakim jest np. las.

Jeszcze inną osią orientacyjną badań wsi jest szeroka perspektywa ekonomiczna. Nie jest ona ograniczona tylko do produkcji rolnej, ale w tej perspektywie analizowane są także inne elementy wiejskiej przestrzeni. Harvey Perkins zwraca np. uwagę w tym kontekście na odkrycie nowych zasobów wsi, które zostają następnie poddane procesom utowarowienia (commodification). Można wręcz powiedzieć, że cała wieś staje się w tym przypadku towarem, który jest sprzedawany w rozmaitych formach. Najbardziej typową formą towarów są oczywiście produkty rolne, nie tylko jednak te tradycyjne, ale też nowe, związane w dużej mierze z produkcją ogrodniczą. Jednak nie tylko one. Towarem są także wiejskie osiedla, wyrastające w procesach dezurbanizacji społeczeństwa (counterurbanization), zaspokajające potrzeby rezydencjalne. Obok nich pojawiają się także rozmaite produkty i typy aktywności związane z wypoczynkiem, turystyką i rekreacją. Jeszcze inną formą wsi jako swoistego produktu są jej medialne obrazy, jej krajobraz, przygotowywane jako materiały promujące obszary wiejskie. Trzeba także pamiętać, że działania na rzecz utowarowienia całej wiejskości spotykają się z rozmaitymi przeciwdziałaniami. Tak można bowiem traktować wysiłki i praktyki podejmowane przez rozmaitych (także lokalnych) aktorów na rzecz „rewitalizacji” obszarów wiejskich, próbujących tworzyć nie tyle produkty do sprzedaży, ile swoiste kulturowe reprezentacje różnych aspektów wiejskości.

Teza, że we współczesnych badaniach dotyczących wsi, w perspektywie ekonomicznej zagubiono jednak specjalne zainteresowanie tradycyjnym typem wiejskiej aktywności ekonomicznej, jakim jest rolnictwo, byłaby przedwczesna i w 
gruncie rzeczy błędna. Dowodem na to są rozważania poświęcone właśnie produkcji rolnej. Rozważania te są prowadzone jednak ze szczególnej perspektywy. Przyjmuje się bowiem założenie, że produkcja rolna nie tylko w krajach wysokorozwiniętych nękana jest poważnym strukturalnym kryzysem. Przyczyną tego kryzysu jest nasilanie się, mimo wszelkich przeciwdziałań, industrialnego i monokulturowego charakteru produkcji rolnej. Diagnoza cokolwiek podobna do tej, jaka została zaprezentowana w koncepcji rolnictwa niezrównoważonego Freda Buttela, ma jednak znacznie szersze konsekwencje. Jest przyczyną pojawienia się nowego typu kwestii agrarnej. Jak stwierdza Jan Douwe van der Ploeg, współczesna kwestia agrarna odnosi się do bardziej ogólnego problemu. Naturalne, jak się kiedyś wydawało, związki pomiędzy rolnictwem, społeczeństwem i przyrodą zostały dogłębnie rozerwane, zaś relacje między rolnictwem i rolnikami przekształcone w kompleksowe i sprzeczne konstelacje, który prowadzą do włączania niewielu i wykluczania wielu. Jest to rezultat tego, iż współczesne rolnictwo znajduje się pomiędzy przysłowiowym „młotem” a „kowadłem”, czyli pomiędzy naciskiem z zewnątrz - ze strony sektora agrobiznesu oraz naciskiem od wewnątrz - ze strony pewnych procesów charakteryzujących samą produkcję rolną. Ten pierwszy polega na zwiększaniu zewnętrznych kosztów obsługi rolnictwa (przede wszystkim są to rosnące koszty nowych technologii), ten drugi zaś na takiej redystrybucji wartości w obrębie rolnictwa, której zasadnicza część trafia do nielicznej grupy największych producentów. Podobnie jak wielu współczesnych badaczy, także van der Ploeg konstruuje normatywną warstwę swojej koncepcji, dzięki której - jego zdaniem - można będzie przeciwdziałać omawianemu kryzysowi, którego efekty są - jak to określa - kontr-produkcyjne, czyli mimo zwiększonej produkcji pociągają za sobą niższy poziom dochodów bezpośrednich producentów (rolników). Program przeciwdziałania ufundowany jest na trzech zasadniczych przesłaniach: (1) zmianie relacji między produkcją rolną a rynkiem (repositioning), (2) stworzeniu zintegrowanej i autonomicznej bazy zasobów będącej w dyspozycji producentów (regrounding), wreszcie (3) wprowadzeniu w większym stopniu społecznego kapitału do produkcji rolnej (self-regulation). Każde z tych przesłań zawiera szereg różnorodnych elementów. I tak, zmiany relacji między produkcją rolną a rynkiem obejmują zróżnicowanie produkcji w poszczególnych gospodarstwach, ponowne włączenie do działań rolników czynności, które zostały powierzone podmiotom zewnętrznym, wprowadzenie nowych wzorców komercyjnych (np. bezpośrednia sprzedaż produktów przez rolników). Z kolei tworzenie bazy zasobów obejmuje „ekologizację” produkcji rolnej oraz podjęcie działań pozaprodukcyjnych, np. na rzecz zachowania krajobrazu wsi. Wreszcie zwiększenie roli kapitału społecznego polega przede wszystkim na odrzuceniu dominujących rozwiązań społeczno-technicznych i skupieniu się na wykorzystaniu wiedzy tradycyjnej, lokalnej czy kooperacji i pomocy sąsiedzkiej.

Szeroka, ekonomiczna oś zainteresowań badawczych dotyczących współczesnej wsi zawiera także problematykę rozwoju obszarów wiejskich oraz próbę 
ujęcia charakteryzujących je nowych mechanizmów. Takim nowym mechanizmem staje się koncepcja rozwoju neo-endogennego, która zawiera w sobie dwa zasadnicze elementy. Pierwszy element odnosi się do określenia endogenny i zawiera ideę rozwoju oddolnego, skupionego na mechanizmach umiejscowionych w pewnej terytorialnej lokalności. Chodzi tutaj o to, że taki rozwój jest jednocześnie rozwojem partycypacyjnym w tym sensie, iż biorą w nim udział zarówno aktorzy, jak i zasoby ulokowane właśnie w owej terytorialnej lokalności. Z kolei określenie „neo-" służy do wskazania na oddziaływanie w tych procesach czynników pozalokalnych. W tym więc sensie neo-endogenny mechanizm rozwojowy jest swoistym połączeniem, hybrydą tradycyjnie rozumianych mechanizmów endo- i egzogennych. Taki mechanizm posiada ponadto dwie istotne charakterystyki. Zarówno działania na rzecz rozwoju ekonomicznego, jak i innych aspektów życia wsi, zorientowane są na korzyści dotyczące określonej społeczności wiejskiej. Temu celowi ma służyć przede wszystkim wykorzystywanie zasobów lokalnych, zarówno fizycznych, jak i ludzkich. Po drugie - jak zaznacza Christopher Ray - zasadniczym kontekstem procesów rozwojowych są potrzeby, zdolności oraz perspektywy członków owej społeczności.

Kolejna oś problemowa współczesnych badań wsi wydaje się dotykać sztandarowego niejako problemu charakteryzującego współczesne społeczeństwo. Chodzi oczywiście o problem globalizacji. Uważny czytelnik tego opracowania zaprotestuje z pewnością, jako że problem ten pojawiał się już np. przy okazji badań dotyczących produkcji rolnej. Jednak w tym przypadku chodzi o problematykę szeroko rozumianej władzy, dominacji czy też regulacji różnych aspektów życia społecznego na obszarach wiejskich. Dobitnie pokazuje to w swoim szkicu Thomas Lyson, skupiając się na zagadnieniach wpływu globalnego kapitału na przeobrażenia społeczności wiejskich. Zasadnicza teza sprowadza się do wskazania, że efekty tego wpływu są raczej negatywne. Zdominowanie określonych społeczności wiejskich przez jedną lub więcej ponadnarodowych korporacji (form obecności globalnego kapitału) przeobraża wiejską społeczność w twór określony mianem społeczności korporacyjnej (corporate community). Funkcjonowanie takiej społeczności odbywa się według reguł neoklasycznej ekonomii, zgodnie z mechanizmami modernizacji i globalizacji. Jest ono skoncentrowane na ekonomicznej sprawności i produktywności, wzroście ekonomicznym, na zorientowanej globalnie masowej produkcji i konsumpcji. Idealną formą organizacji produkcji jest wielka firma zorientowana na globalne rynki i konkurująca na nich. Tkanka społeczna zdominowana jest przez członków korporacyjnej klasy średniej, profesjonalistów, menedżerów, technokratów, a motorem rozwoju są mechanizmy wolnego rynku, ludzki kapitał i indywidualne działania. W przeciwieństwie do takiego typu Lyson konstruuje model społeczności obywatelskiej, opartej na zasadach rozwoju zrównoważonego i dowartościowaniu zasobów lokalnych. Model rozwoju jest tutaj zorientowany na równość społeczną i ekonomiczną, dobrostan całej społeczności i poszczególnych gospodarstw domowych, lokalną produkcję 
i konsumpcję. Produkcja jest prowadzona w mniejszych, lokalnie kontrolowanych przedsiębiorstwach, zaś handel zdominowany przez regionalne stowarzyszenia i spółdzielnie. Idealną formą organizacji biznesu jest mała firma. Tkankę społeczną tworzą członkowie niezależnej klasy średniej, przedsiębiorcy, samozatrudniający się profesjonaliści oraz rolnicy. Motorem rozwoju jest obywatelskie zaangażowanie, różne stowarzyszenia czy też ruchy społeczne. Społeczność taka, w przeciwieństwie do korporacyjnej, jest też ostoją demokracji. Autor zdaje sobie oczywiście sprawę z normatywnego czy też postulatywnego raczej charakteru swojego wywodu. Niemniej uważa, że przeciwstawienie się modelowi korporacyjnej społeczności jest szansą na zachowanie społeczności lokalnych, jako elementu współczesnego społeczeństwa.

W dwóch kolejnych odsłonach problematyka władzy zostaje zorientowana na kwestie regulacji oraz działalność państwa. W pierwszym szkicu Mark Goodwin wskazuje na konieczność analiz dotyczących rozmaitych zabiegów regulacyjnych zarówno przez aktorów ekonomicznych, jak i tych spoza tej sfery, odnoszących się do gospodarki, jak i innych aspektów życia wsi. Program badań dotyczy tutaj np. przyjrzenia się rozmaitym sposobom przezwyciężania zjawisk kryzysowych, zarówno w skali globalnej, jak i na poziomie społeczności lokalnych. Szczególnie podkreślona zostaje rola kultury i systemów znaczeń wypracowanych w różnych społecznościach wiejskich. Perspektywa regulacyjna umożliwia w ten sposób analizę powiązań między wiejską gospodarką, społeczeństwem i instytucjami politycznymi - i tym sposobem pomaga wydobyć specyficzne cechy oraz jednocześnie zróżnicowanie procesów zmian zachodzących na wsi. Z kolei Alessandro Bonnano w swoich rozważaniach koncentruje się wyłącznie na roli i znaczeniu państwa w kontekście funkcjonowania instytucji politycznych na wsi. Wskazuje na cztery obszary koniecznych analiz. Pierwszy z nich dotyczy wpływu kryzysu państwa (nation-state) na funkcjonowanie słabszych grup społecznych (przede wszystkim wiejskich), które do tej pory wykorzystywały państwo jako pomost dla wyrażania swoich potrzeb i aspiracji. Innym zagadnieniem wymagającym uwagi także w kontekście problematyki wsi jest pojawianie się ponadnarodowych form państwa. Stanowi to zagrożenie - zdaniem autora - dla interesów społeczności wiejskich kosztem interesów ponadnarodowego kapitału. $\mathrm{Z}$ drugiej jednak strony może to stanowić swoistą inspirację dla pojawienia się rozmaitych lokalnych inicjatyw i działań, do tej pory postrzeganych jako domena instytucji państwowych. To wycofywanie się państwa ze sfer dawniej regulowanych przez jego rozmaite polityki wymaga także szczególnego zainteresowania badaczy. Czy jest szansa powstania w to miejsce jakichś nowych form państwa - „państwa ponadnarodowego", jakichś regulacyjnych struktur na poziomie regionalnym czy lokalnym? Te kwestie stanowią przedmiot dzisiejszej dyskusji.

Kolejna oś problemowa współczesnych badań wsi dotyczy problematyki konsumpcji. Podobnie jak w przypadku gospodarki, współczesny konsumpcjonizm na wsi określony zostaje mianem nowego. Pierwszy aspekt tego zagadnienia 
związany jest z napływem na wieś, przede wszystkim jednak na te jej obszary, które są położone bliżej miast, osób, które nie są zainteresowane rolnictwem, ale raczej komfortem i niższymi kosztami swojego zamieszkania. Sonya Salamon zwraca uwagę, że w tym tworzącym się niejako wiejskim społeczeństwie post-agrarnym ziemia nabiera innego znaczenia, jako walor, który dostarcza estetycznych doświadczeń obcowania z przyrodą czy też widoku otwartej przestrzeni tym, którzy żyją na wsi, ale nie są związani z działalnością produkcyjną. Zmiana ta dotyczy zresztą nie tylko ziemi, ale także całej w gruncie rzeczy materialnej kultury rolnej. Jak powiada Salamon, konsumpcja materialnej kultury w formie starych narzędzi z gospodarstwa rolnego, naczyń kuchennych, tkanin tworzy w szerszym społeczeństwie podstawę zmiany w postrzeganiu tego, co jest uznane za sztukę czy wysoką kulturę, a używanie wytworów wiejskiej kultury materialnej, cenionych teraz jako przejawy sztuki, zezwala na przekształcenie regionalnych i narodowych tożsamości i stanowi afirmację pluralizmu kulturowego. Nasilenie procesów napływu na wieś osób niezwiązanych z rolnictwem owocuje także szeroką gamą przemian całego wiejskiego krajobrazu. Procesy te wyzwalają przede wszystkim rozmaite konflikty. Dotyczą one sporów między rolnikami - którzy próbują w dalszym ciągu wykorzystywać wiejską przestrzeń w sposób, nazwijmy to, tradycyjny, czyli jako obszar praktyk produkcyjnych, a nowymi mieszkańcami (owymi „podmieszczuchami”, suburbanites) - którym owe praktyki produkcyjne zaburzają sposób odbioru i wykorzystania wiejskiej przestrzeni. Inny rodzaj konfliktu powodowany jest przez napływ na wieś podmiejską osób o niskich dochodach, które przenoszą się na ten obszar w celu obniżenia kosztów zamieszkania. Przynoszą jednak ze sobą określone nawyki, wykształcone w okresie zamieszkiwania w ubogich dzielnicach wielkomiejskich, które stoją w sprzeczności z nawykami i wzorami zachowań dawnych mieszkańców wsi. Wreszcie inny jeszcze typ przemian wsi związany jest z przejmowaniem przez mieszkańców wsi (także rolników) określonych wzorów, przynoszonych przez przybyszy z miasta. Salamon wskazuje tutaj np. na zamianę tradycyjnych ogrodów warzywnych przy zabudowaniach mieszkalnych na farmach w ogrody dekoracyjne $\mathrm{z}$ trawnikami, drewnianymi czy gipsowymi rzeźbami itp.

Innymi aspektami problematyki konsumpcji w odniesieniu do obszarów wiejskich stają się kwestie spożywania żywności oraz turystyka. Socjologia żywności (sociology of food), bo tak bywa określana ta, w gruncie rzeczy, nowa subdyscyplina zajmująca coraz bardziej istotne miejsce w studiach dotyczących wsi (ale nie tylko), skupiona jest przede wszystkim na społecznym charakterze i znaczeniu praktyk związanych z konsumpcją żywności. W propozycjach tworzonych w ramach tego nurtu przez rozmaitych autorów zwraca się uwagę na powiązania charakteru i sposobu takiej konsumpcji z przynależnością klasową i rosnącą w coraz większym stopniu indywidualizacją tego typu aktywności, która ma potwierdzać nie tyle przynależność do określonej kategorii społecznej, ile stanowić element kreowania własnej tożsamości. Spożywanie żywności 
staje się we współczesnym społeczeństwie (zwłaszcza w społeczeństwach wysokorozwiniętych) coraz bardziej praktyką typu refleksyjnego, czego najlepszym przykładem może być działalność ruchu Slow Food. Wyrazem łączenia starych i nowych (zwykłych i refleksyjnych) praktyk konsumpcyjnych są też takie analizowane przez badaczy inicjatywy jak bezpośrednia sprzedaż towarów przez rolników konsumentom (tzw. rynki rolników) oraz produkcja i dystrybucja żywności produkowanej metodami ekologicznymi. Warto podkreślić, że wskazane wyżej praktyki związane z konsumpcją żywności mogą stanowić istotny element strategii rozwoju zrównoważonych łańcuchów żywnościowych. Jak podkreśla Mara Miele, taka konceptualizacja może sprzyjać zrozumieniu warunków dla przyjaznych środowisku praktyk konsumpcyjnych i tworzyć platformę dla oszacowania możliwości i strategii promowania zrównoważenia w łańcuchach żywnościowych. Z kolei David Crouch wskazuje na rolę turystyki w odniesieniu do obszarów wiejskich. Traktowanie turystyki jako swoistego sposobu konsumowania wiejskości sprzyja utowarowieniu wsi. Ale nie tylko. Turyści stają się w coraz większym stopniu aktorami uczestniczącymi w procesie przekształcania wsi, nadawania jej nowych znaczeń czy tworzenia nowych jej wyobrażeń. Turyści współkonstytuują zatem współczesną wiejskość.

Kolejnym polem badawczym we współczesnych studiach wsi jest problematyka tożsamości. W tym obszarze w sposób najbardziej zdecydowany - w moim przeświadczeniu - można zaobserwować zjawisko swoistej kontynuacji i zmiany w badaniach wsi. Problematyka tożsamości pojawiała się z reguły poprzednio w odniesieniu do przemian producentów rolnych. Analizowano rozmaite aspekty przemian chłopów w nowoczesnych rolników, przyglądano się powstawaniu różnych typów producentów rolnych, podejmowano też kwestie tożsamości w odniesieniu do osób łączących pracę w gospodarstwie z pracą poza nim oraz osób zajmujących rozmaite położenia w systemie stosunków klasowych, jaki powstał w systemie produkcyjnym rolnictwa. Obecnie jednak problem tożsamości jest ujmowany przez badaczy wsi znacznie szerzej. Wydaje się, że stanowi to rezultat oddziaływania dwojakiego rodzaju czynników. Z jednej strony wyraźnego wzrostu zainteresowania problemami tożsamości, stanowiącego odbicie zwrotu kulturowego w naukach społecznych i zdecydowanie większego aniżeli kiedyś przywiązywania wagi do problematyki wyobrażeń, obrazów, tworzenia wizerunków samego siebie czy innych. $Z$ drugiej strony jest to wynikiem także odmiennego spojrzenia na samą wieś, która w perspektywie badaczy przestała już być tylko i wyłącznie miejscem praktyk produkcyjnych (głównie w obszarze rolnictwa), stając się jednocześnie obszarem różnorodnych działań konsumpcyjnych. Świadczy o tym chociażby cała gama problemów badawczych charakteryzowanych wyżej w tym opracowaniu. Świadczą też o tym uwagi trójki badaczy poświęcone rozmaitym aspektom problematyki tożsamości na wsi, o czym poniżej.

Ten ostatni wątek badań otwierają rozważania Jo Little dotyczące problematyki płci społeczno-kulturowej (gender) oraz seksualności w społecznościach 
wiejskich. Punktem wyjścia jest krytyka tradycyjnej „rolniczej” pespektywy konceptualizacji wiejskości, w której zawarta jest wyraźna dominacja mężczyzn - wykonujących najważniejsze prace i niedocenianie roli kobiet - zredukowanych w dużej mierze do wykonywania zadań „domowych”. Sytuacja ta ulega jednak zmianie nie tylko z uwagi np. na rosnące znaczenie koncepcji i ruchów feministycznych, ale też przemiany technologiczne, które redukując potrzebę siły fizycznej podczas wykonywania wielu prac w gospodarstwie, w paradoksalny sposób przyczyniają się do zrównania pozycji kobiet i mężczyzn. Rola i znaczenie kobiet wzrastają także $\mathrm{z}$ uwagi na przeobrażenia funkcji obszarów wiejskich. Innym zagadnieniem, które pojawia się w tym kontekście, jest problematyka zmysłów i emocji, które powinny zostać - zdaniem autorki - włączone do badań roli tożsamości płciowej w procesach konstruowania współczesnego obrazu wiejskości. W kolejnym szkicu Paul Cloke zajmuje się kwestią etniczno-rasowych relacji na wsi, sytuując tę kwestię w kontekście problematyki „obcych” i generalnie „inności” (otherness). Nabiera to szczególnego znaczenia w kontekście tradycyjnego zamknięcia społeczności wiejskich, a także homogeniczności i „czystości” przestrzeni wiejskiej, jako „swojskiej”, zamieszkanej przede wszystkim przez „swoich”. Nabiera to też szczególnej roli w konkretno-historycznym kontekście wsi angielskiej - a to ona jest przede wszystkim obiektem zainteresowań autora - której obraz bywa rekonstruowany jako istota tradycji narodowej. Ta koncepcja potwierdzona zostaje następnie opisem przypadków nietolerancji rasowej, doświadczanej przez przybyszów z różnych regionów świata, którzy porzucając bardziej kosmopolityczne brytyjskie miasta, próbują wnikać na angielską wieś. Uzupełnieniem tych rozważań jest ukazanie sytuacji osób starszych w jednym z wiejskich regionów Nowej Zelandii. Jak podkreślają Lex Chalmers i Alun Joseph, dominujący dyskurs dotyczący zrównoważonego rozwoju wsi i miar jego sukcesu konstruowany jest w oparciu o prymat wartości związanych z przedsiębiorczością, a nie w oparciu o doświadczenia życiowe różnych kategorii mieszkańców, w tym szczególnie zmarginalizowaną grupę osób w podeszłym wieku.

Ostatnia oś zainteresowań badawczych współczesną wsią dotyczy problematyki wykluczania. W pierwszym z trzech szkiców poświęconych temu zagadnieniu David Sibley podkreśla, że próby formułowania jakichkolwiek uogólnień dotyczących wykluczania czy, odwrotnie, włączania w odniesieniu do wsi jako takiej pozbawione są większego sensu. Różnorodność poszczególnych wiejskich obszarów, ich szczególna historia, rozmaita symbolika związana z różnie rozumianą wiejskością w różnych społeczeństwach i kulturach praktycznie uniemożliwiają tego rodzaju przedsięwzięcie. Możliwe są co najwyżej do wykorzystania w każdym przypadku wypracowane już wcześniej w odniesieniu do miasta koncepcje społeczno-psychologicznej konstrukcji przestrzeni (np. propozycja Richarda Sennetta), czy też - proponowane przez samego autora - niektóry pomysły z kręgu szkoły psychoanalitycznej. Problemy wykluczania są przez Sibleya definiowane jako obawa dotycząca różnic społecznych, dlatego też w perspektywie badawczej 
konieczne jest - jego zdaniem - połączenie perspektywy psychologii społecznej i psychoanalizy z elementami analizy etnograficznej, skupionych na dwóch zasadniczych kwestiach, czyli problematyce tożsamości i miejsca oraz uczuciach wobec innych.

Kolejne dwa opracowania poświęcone są już bardziej konkretnym przejawom wykluczania na obszarach wiejskich, czyli problemom ubóstwa oraz bezdomności. W skali świata, zwłaszcza w społeczeństwach słabiej rozwiniętych, wiejskie ubóstwo stanowi dominującą formę deprywacji. Co jednak ważne, także w krajach wysokorozwiniętych wiejskie ubóstwo jest nieproporcjonalnie większe i bardziej dolegliwe aniżeli na obszarach miejskich. Paradoksalnie jednak - zdaniem Ann Tickmayer - to ubóstwo w miastach skupia na sobie bardziej uwage zarówno badaczy, jak i polityków. Trzeba także pamiętać, że zrozumienie różnych form czy postaci ubóstwa (także na wsi) jest niemożliwe bez zwrócenia uwagi na historycznie specyficzne wzory, procesy oraz instytucje, które ukształtowały rozmaite społeczeństwa i ich kultury. Podobnie zatem także David Sibley jest przekonany, że różnorodność, jaka istnieje pomiędzy rozmaitymi wiejskimi przestrzeniami i miejscami, jeśli chodzi o społeczne, demograficzne, polityczne i ekonomiczne procesy rozwoju poszczególnych grup i regionów, oznacza, że żadne ujęcie teoretyczne nie jest w stanie objąć wszystkich możliwych przypadków.

Problem bezdomności na wsi wymaga zdecydowanie większej uwagi i szerszych aniżeli dotychczas badań. Autor tego opracowania, Paul Milbourne, wskazuje na swoistą niewidoczność problemu bezdomności na wsi. Jego zdaniem odpowiedzialne są za to dwa czynniki. Pierwszy z nich wiąże się z rozproszoną zabudową wsi, drugi natomiast $-\mathrm{z}$ brakiem na obszarach wiejskich instytucji mających służyć bezdomnym, takich jak np. schroniska, hostele czy miejsca, gdzie osoby bezdomne mogłyby spędzić jakąś część dnia. Specyfika wiejskiej bezdomności lokowana jest przede wszystkim w szerszym (aniżeli w miastach) zjawisku balansowania na „granicy bezdomności”. Osoby bezdomne na wsi częściej próbują rozwiązać ten problem czasowo, „pomieszkując” z członkami rodzin. Częściej aniżeli w miastach decydują się na zamieszkanie w nieodpowiednich czy niebezpiecznych warunkach. Częściej też zmieniają swoje miejsce pobytu. Powoduje to, że wiele osób doświadczających faktycznie bezdomności na wsi nie rozpoznaje swojej sytuacji jako ,nieposiadania własnego dachu nad głową”. Innym czynnikiem sprzyjającym eliminacji bezdomności na wsi jest tradycyjnie uporządkowany i klarowny obraz tej przestrzeni, gdzie wszelkie „niewłaściwe” osoby czy praktyki są usuwane poza granice miejsc. Wszystko to powoduje, że powstaje pilna potrzeba analiz $\mathrm{w}$ trzech obszarach. Po pierwsze, potrzebne są badania sytuujące problem relacji między warunkami mieszkaniowymi na wsi a bezdomnością w szerszym, społeczno-kulturowym, ekonomicznym i politycznym kontekście. Po drugie, istnieje potrzeba bliższej analizy powiązań pomiędzy poszczególnymi elementami systemu mieszkaniowego na wsi. Po trzecie, pożądane jest bliższe przyjrzenie się znaczącym powiązaniom pomiędzy warunkami mieszkaniowymi na wsi a wiejską bezdomnością. 


\section{International Handbook of Rural Studies}

Opracowanie zbiorowe (por. Shucksmith, Brown, 2016) noszące tytuł International Handbook of Rural Studies zawiera w sumie dużo więcej, niż omówione wyżej Handbook of Rural Studies, bo aż 55 artykułów, z czego dwa można od tej liczby odliczyć, jako że jeden to swoiste wprowadzenie, zatytułowane „Farming Rural Studies in the Global North", a drugi to zakończenie, zamieszczone w specjalnej części zatytułowanej „Conclusion” w jedynym w tej partii rozdziale pt. „Rural Studies: The Challenges Ahead”. Warto zauważyć, że obecność wprowadzenia i zakończenia, przygotowanych przez obydwu redaktorów tomu, jest tym, co odróżnia go od wcześniejszej publikacji. Ponadto obydwa te fragmenty opracowania są bardzo obszerne. Liczą odpowiednio: 26 stron (Wprowadzenie), 42 strony (Konkluzje). Pomijając jednak te dwa fragmenty, możemy powiedzieć, że prezentowane opracowanie zawiera 53 artykuły, które zostały zgrupowane w ośmiu zasadniczych częściach, o czym będzie jeszcze mowa poniżej. Inaczej niż w poprzednim tomie, więcej rozdziałów jest tutaj efektem pracy kolektywnej (dwu-, a nawet trzyosobowych zespołów). Takich rozdziałów jest w sumie 27, na - przypomnijmy - $53 \mathrm{w}$ sumie, zatem $\mathrm{w}$ gruncie rzeczy połowa.

Zacznijmy zatem analizę od zaprezentowania Wprowadzenia. Jak wcześniej zaznaczyłem, inaczej niż we wcześniejszym tomie, gdzie pojawiło się tylko krótkie (dwustronicowe) i niezobowiązujące (niepodpisane nawet przez redaktorów) „Preface”, w analizowanej monografii mamy do czynienia z obszernym (liczącym dobrze ponad dwadzieścia stron) wstępem, posiadającym merytoryczny profil oraz sygnowanym nazwiskami dwóch znanych badaczy z zakresu współczesnej socjologii wsi. Podobnie jak redaktorzy poprzedniego tomu, są to badacze z kręgu brytyjsko-amerykańskiej społeczności. Mark Shucksmith jest obecnie dyrektorem ulokowanego w Uniwersytecie Newcastle Institute of Social Renewal (Wielka Brytania), zaś David L. Brown pełni funkcję International Professor of Development Sociology oraz jednego z dyrektorów Instytutu Badań nad Społecznościami i Regionalnym Rozwojem w Cornell University w Stanach Zjednoczonych. Wprowadzenie do monografii, przygotowane przez obu tych badaczy, nie pozostawia wątpliwości. Chodzi bowiem o - jak wskazuje jego tytuł - ujęcie analiz dotyczących obszarów wiejskich tzw. Globalnej Północy. Oznacza to ni mniej ni więcej tylko to, że międzynarodowe kwestie związane z badaniami obszarów wiejskich są - w gruncie rzeczy - utożsamiane z zagadnieniami, jakie są przede wszystkim podejmowane w odniesieniu do obszarów wiejskich Europy Zachodniej i Ameryki Północnej. Autorzy rozdziału wstępnego podkreślają, że rozważania zawarte w monografii dotyczą właśnie bardziej rozwiniętych regionów współczesnego świata oraz że zawierać powinny nowe treści i zagadnienia w porównaniu z wydanym dziesięć lat wcześniej tomem. Wskazują ponadto na kilka wiodących tematów, jakie tworzą ramy dyskursów zawartych w prezentowanym tomie. Tematy te dotyczą istoty tego, czym jest „wiejskość” (rural), zawierają 
narracje poświęcone zmianom obszarów wiejskich oraz specyficznym ujęciom tematycznym, skoncentrowanym na różnych aspektach ich funkcjonowania oraz dynamiki. W ramach tych ostatnich mowa jest o powiązaniach między różnymi fragmentami przestrzeni (miejscami) oraz między przyrodą a społeczeństwem, wzrastających nierównościach, fiskalnym kryzysie państwa oraz obszarach wiejskich jako miejscach oporu wobec neoliberalnej globalizacji. W konkluzywnych (w ramach wprowadzenia) uwagach obaj autorzy konstruują współczesny model socjologii wsi, która - wedle ich opinii - jest raczej zestawem analiz zorientowanych na określone problemy aniżeli jakąś w miarę spójną subdyscypliną. Ta teza jest zatem zasadniczo odmienna od przesłania zawartego w poprzednim tomie.

Warto spojrzeć na te typy analiz, jako że są one związane z kilkoma zasadniczymi kwestiami czy pytaniami, które zostały zaznaczone przez autorów. Trzeba w tym miejscu może zacytować stosowny fragment:

„We współczesnym świecie globalizacja, zmiany technologiczne, wzrost oraz spadek populacji, starzenie się społeczeństw, migracje, wzrastające zapotrzebowanie na energię, żywność oraz surowce, jak również nieprzewidywalność kapitalistycznego wzrostu ekonomicznego, stwarzają zarówno dla rządów, jak i obywateli poszczególnych państw potężne wyzwania, na które nie ma prostych i oczywistych odpowiedzi. Stare pewniki i podstawowe założenia dotyczące światowego porządku, które określały nasze myślenie od końca II wojny światowej, wydają się obecnie bez znaczenia. Wzrasta potrzeba świeżego spojrzenia na rozmaite kwestie oraz konstruowania najlepszych odpowiedzi na nierozwiązane niepewności wynikające z wojny oraz z takich wyzwań obecnego wieku, jak: zadłużenie państw, chwiejny wzrost ekonomiczny, wzrastające bezrobocie, zwłaszcza wśród młodszego pokolenia, upadek społeczności, wzrastające nierówności w dochodach, poziomie zdrowotności czy w odniesieniu do poziomów wykształcenia i bogactwa. Dla wielu ludzi niemożność sformułowania satysfakcjonujących odpowiedzi na te kwestie wzmacnia ich poczucie bezsilności, co zagraża podstawom reguł polityki oraz legitymizacji władzy na wszystkich poziomach" (Shucksmith, Brown, 2016: 17).

Redaktorzy wskazują, że odpowiedzi na te pytania mogą być zawarte w poszczególnych rozdziałach omawianej monografii.

Zasadniczą część prezentowanego tomu stanowią 53 rozdziały zamieszczone w ośmiu szerszych całościach (częściach). Warto wskazać na ich zakres tematyczny, posiłkując się jednocześnie zamieszczonymi w publikacji tytułami. Obejmują one zatem kolejno: zmiany demograficzne (sześć rozdziałów), zmiany ekonomiczne (siedem rozdziałów), kwestie dotyczące systemów żywnościowych oraz ziemi uprawnej (siedem rozdziałów), środowisko i zasoby (siedem rozdziałów), zagadnienia płci społeczno-kulturowej w odniesieniu do obszarów wiejskich (siedem rozdziałów), społeczne i ekonomiczne (nie)równości (sześć rozdziałów), dynamikę społeczną i zmiany instytucjonalne (siedem rozdziałów) oraz władzę i współrządzenie (sześć rozdziałów). 
Część pierwsza poświęcona jest problemom ludnościowym. Rozpoczyna ją analiza istoty zachodzących obecnie zmian demograficznych, które dokonują się niejako poza dotychczas istniejącymi, tradycyjnymi podziałami na miasto i wieś. Większa fizyczna czy też przestrzenna ruchliwość ludzi współcześnie owocuje też zwiększoną dynamiką w wymiarze ruchliwości społecznej. Podkreśla się także konieczność uwzględniania rozmaitych perspektyw teoretycznych, w szczególności wyjścia poza tradycyjne pozytywistyczne ujęcia. Samo pojęcie wiejskości staje się obecnie koncepcją bardziej złożoną, niejednoznaczną, zróżnicowaną, stąd wzrastająca tendencja do mówieniu raczej o populacji na wiejskich obszarach czy po prostu o populacji w miejsce dawniej powszechnie używanej koncepcji „populacji wiejskiej”. Podkreśla się, że przemiany demograficzne na wsi nie zachodzą w społecznej, ekonomicznej czy politycznej próżni, stąd nacisk raczej na analizę bardziej konkretnych, wybranych zjawisk czy procesów społecznych. W prezentowanym tomie analizy ograniczone są do obszarów tzw. Globalnej Północy współczesnego świata. Generalnie obserwowane trendy to raczej spadek zaludnienia obszarów wiejskich, z pewnymi jednak wyjątkami dotyczącymi obszarów ulokowanych w pobliżu wielkich metropolii oraz tych społeczności czy regionów, które dysponują specyficznymi czy cennymi zasobami. Warto też podkreślać, że także w obrębie owej Globalnej Północy można zaobserwować pewną niejednolitość trendów demograficznych. Istotne czynniki kształtujące przede wszystkim demograficzny kształt dzisiejszej Globalnej Północy to zmiany ekonomiczne (tendencje w kierunku tworzenia gospodarki opartej na wiedzy, bardziej intensywne procesy migracyjne, prowadzące także do wykluczenia, starzenie się ludności oraz jej problemy zdrowotne).

Drugi obszar analiz prezentowanych w omawianym tomie dotyczy przeobrażeń ekonomicznych, a w szczególności rozeznania co do roli i znaczenia czynników wzrostu gospodarczego. Punktem wyjścia podejmowanych analiz jest szczególne ujęcie współczesnej gospodarki jako typu aktywności opierającego się na trzech elementach: szczególnej wadze powiązań (sieci), szczególnej roli tzw. efektu aglomeracyjnego (skupienia) wpływającego na produktywność oraz znaczenia innowacji jako czynnika wzrostu. Pierwszy z tych czynników stanowi tradycyjna słabość obszarów wiejskich rozumianych $w$ historycznej perspektywie jako tych marginalizowanych, słabiej połączonych z resztą organizmu ekonomiczno-społecznego. Wskazuje się jednak, że nowoczesne technologie komunikacji stanowią ważny czynnik przezwyciężania tej niedogodności. Ponadto charakteryzujące się mniejszą gęstością zaludnienia obszary wiejskie stanowią podstawę do kształtowania się słabszych rynków dla lokalnych firm. Wzmocnienie tych rynków może nastąpić przede wszystkim w rezultacie ich silniejszego połączenia z szerszymi strukturami. Stąd np. większa dynamika ekonomiczna tych obszarów wiejskich, które położone są bliżej obszarów metropolitalnych. Obszary wiejskie nie są też postrzegane (w przeciwieństwie do dużych obszarów miejskich) jako innowacyjne w sensie opracowywania przez ekspertów nowych rozwiązań uzyskujących patenty. Jednak na 
obszarach wiejskich można zaobserwować częściej nieco inny typ innowacji, który powiązany jest $\mathrm{z}$ działalnością pojedynczych osób i/lub niewielkich grup. Podkreśla się ponadto, że na obszarach wiejskich ulokowane są z reguły prostsze i bardziej podstawowe typy usług (np. w dziedzinie zdrowia czy edukacji). Istotna jest też konieczność otwarcia gospodarek wiejskich na rynek zewnętrzny, tak aby mogły one zaopatrywać go w rozmaite towary i usługi, których tworzenie na terenach miejskich jest niemożliwe. Wskazuje się też, że rynek pracy na obszarach wiejskich jest i uboższy w oferty, i mniej wymagający, jeśli chodzi o kwalifikacje pracowników. Wszystko to nie sprzyja wyrównywaniu różnic między obszarami miejskimi i wiejskimi. Dążenie do zmiany tej sytuacji wymaga większego powiązania gospodarki wiejskiej z obszarami pozawiejskimi, ochrony naturalnych zasobów, które ulokowane są przede wszystkim na obszarach wiejskich oraz jej (gospodarki wiejskiej) konkurencyjności, która jest efektem koncentracji na produkcji specyficznych dóbr i usług oraz wzrastającej produktywności.

W trzeciej części rozważana jest kwestia tradycyjnie najważniejszego czynnika produkcji w rolnictwie, czy szerzej w systemie produkcji żywności, jakim jest ziemia. Wskazuje się w tym kontekście na trzy typy systemów produkcji żywności, które określa się mianem: tradycyjnego, modernizującego się oraz industrialnego (przemysłowego). Ten ostatni występuje przede wszystkim w krajach Globalnej Północy. Pojawienie się, rozprzestrzenianie i dominacja w sensie przede wszystkim wolumenu produkcji jest w dużej mierze efektem zachodzących procesów globalizacyjnych, rezultatem stosowanych neoliberalnych rozwiązań w zakresie polityki ekonomicznej oraz uzyskiwania dominującej roli przez struktury finansowe ponadnarodowego kapitału (tzw. finansjalizacja sektora produkcji żywności). Ten dominujący niejako trend rodzi jednak idee innego modelu rozwojowego. Zwraca się w nich uwagę na kwestie ekologiczne (agroekologia), przeciwdziałanie koncentracji produkcji (która jest pochodną globalizacji i finansjalizacji) i powiązania produkcji rolnej z innymi przemianami obszarów wiejskich.

Niejako w naturalny sposób w czwartej części opracowania zwraca się uwagę na kwestie środowiska oraz zasobów, jakie są rozmieszczone na obszarach wiejskich. Rozważana jest w tym kontekście idea powrotu do wygaszanych w dużej mierze (na obszarach Globalnej Północy) przemysłów wydobywczych. Zdecydowanie trudniejsza do realizacji jest ta nowa koncepcja w krajach Unii Europejskiej, gdzie obowiązują bardziej restrykcyjne (niż np. w Stanach Zjednoczonych) regulacje, chociażby w ramach Programu NATURA 2000. Takie myślenie nie jest jednak obce i w Europie, czego dowodzi - moim zdaniem - ostatnia eksplozja rabunkowej gospodarki leśnej np. w Polsce pod pretekstem ochrony środowiska i zapewnienia bezpieczeństwa. Innym przejawem działań i kontrowersji wokół środowiska naturalnego i zasobów na obszarach wiejskich są spory wokół źródeł energii odnawialnej, uwidoczniające rozmaite, często przeciwstawne interesy. Zachowanie bioróżnorodności i przywracanie pierwotnego charakteru obszarom wiejskim (rewilding policies) są przedmiotem ścierających się różnych dyskursów, 
prezentowanych przez różnych aktorów. Pojawiają się też silne tendencje do przedefiniowywania zasobów wiejskich, które przy pomocy najnowszych technologii mogą być przekształcane w nowe rodzaje produktów (np. wykorzystywanie biomasy w procesie wytwarzania odzieży). Zdaniem autorów zajmujących się tymi zagadnieniami istnieje pilna potrzeba nie tyle konsolidowania i integrowania tradycyjnych podejść do ekologii na obszarach wiejskich, ile poszukiwania nowych rozwiązań $\mathrm{w}$ odpowiedzi na nowe, globalne kwestie związane $\mathrm{z}$ odnawianiem zasobów, produkcją energii itp.

Kolejny obszar tematyczny, z jakim można się spotkać w omawianym tomie, to zagadnienia płci społeczno-kulturowej (gender) w kontekście społeczności wiejskich. W tym obszarze omawiana jest zarówno zmiana dotycząca dyskursu na ten temat w ostatnich latach, jak i - przede wszystkim - kierunki przyszłych badań. Wskazuje się, że jakkolwiek w rzeczywistości można zaobserwować bardziej istotną rolę kobiet zarówno w obrębie gospodarstw rolnych, jak i w społecznościach wiejskich czy strukturach samorządowych, to jednak w ramach obecnych dyskursów rola kobiet jest wciąż drugoplanowa i odzwierciedla niejako ich podporządkowaną pozycję. Dlatego też konieczne są bardziej wnikliwe analizy, skoncentrowane na interakcjach społecznych i procesach konstruowania tożsamości. W związku z tym pożądane obszary badawcze w tym zakresie dotyczą kwestii płci społeczno-kulturowej w kontekście przedsiębiorczości, przywództwa, zarządzania/współrządzenia (governance), prowadzenia gospodarstw rolnych itp.

Problematyka społecznych i ekonomicznych (nie)równości wyznacza kolejny obszar zainteresowań badawczych współczesnych analiz obszarów wiejskich. Dzieje się tak przede wszystkim dlatego, że społeczne i ekonomiczne nierówności wydają się obecnie ponownie narastać zarówno w odniesieniu do międzynarodowych porównań, jak i pomiędzy poszczególnymi grupami czy kategoriami społecznymi w określonych krajach. Wiąże się to $\mathrm{z}$ wieloma czynnikami, wśród których warto wymienić globalny kryzys finansowy, redukcję zaangażowania państwa w finansowanie np. polityk publicznych, restrukturyzację gospodarki, procesy depopulacji i starzenia się wielu obszarów wiejskich w krajach Globalnej Północy itp. Problem wspomnianych nierówności nabiera szczególnego znaczenia w kontekście porównywania obszarów wiejskich z ,resztą” społeczeństwa, a przejawia się przede wszystkim w gorszym dostępie do usług, gorszej ofercie na rynku pracy, ograniczeniami w dostępie do ziemi itd. Problemy nierówności są w odniesieniu do obszarów wiejskich Globalnej Północy ujmowane przede wszystkim w dwóch istotnych perspektywach. W Stanach Zjednoczonych są to w głównej mierze studia dotyczące różnych przejawów ubóstwa, zaś w Europie badacze posługują się głównie szerszą koncepcją wykluczenia. Badania te podejmowane są także w kontekście nierówności przestrzennych, zróżnicowania etnicznego czy też problemów mieszkalnictwa.

Inny obszar analiz dotyczy dynamiki oraz przemian organizacji społecznej obszarów wiejskich. Wskazuje się w tym kontekście na sposoby funkcjonowania wiejskich społeczności lokalnych, organizację życia społecznego ich mieszkańców, 
sposoby definiowania miejsc, czyli niejako udomowionych fragmentów przestrzeni społecznej i kulturowej, procesy kształtowania się tożsamości i instytucji w wymiarze lokalnym, narodowym czy też z odniesieniem do kontekstu globalnego. Organizacja i dobrostan wiejskich miejsc są tutaj z jednej strony ujmowane w kategoriach instytucjonalnych, ze szczególnym uwzględnieniem struktur ekonomicznych, powiązanych z lokalnymi instytucjami i ośrodkami zarządzania. W tym kontekście rozważane są także kwestie decentralizacji, prywatyzacji, zwłaszcza w odniesieniu do usług publicznych na obszarach wiejskich, co wzmacnia dodatkowo ich strukturalnie niekorzystną sytuację. Ważną rolę w tym kontekście odgrywa edukacja, której funkcje mogą jednak być niejednoznaczne. $Z$ jednej strony wydaje się ona sprzyjać podniesieniu poziomu wykształcenia mieszkańców, z drugiej zaś - może wzmacniać tendencje do migracji poza obszary wiejskie. Ważną rolę odgrywają tutaj także różne rodzaje dyskursu tworzące bądź wyidealizowany obraz wsi, bądź też utożsamiające ją z ośrodkiem nie-nowoczesności i braku perspektyw. Podkreśla się też mocno, że obszary wiejskie, tak jak całe społeczeństwo, stanowią dzisiaj swoistą przestrzeń przepływów ludzi, kapitału, informacji czy też wartości.

Ostatni obszar tematyczny dotyczy władzy (power) i współrządzenia (governance). Istotnych jest tutaj kilka wątków tematycznych. Pierwszy dotyczy demokratyzacji władzy, w szczególnym stopniu na poziomie lokalnym, która zaczyna być dzielona pomiędzy różnych aktorów posiadających istotne interesy. W tym kontekście szczególnie podkreślona zostaje rola swoistego konfliktu pomiędzy grupami reprezentującymi poziom narodowy oraz także lokalny a bezpośrednimi reprezentantami mieszkańców określonych społeczności czy obszarów. Innym aspektem tej sytuacji jest analiza zdolności mobilizacyjnych mieszkańców, tworzących ruchy protestacyjne w obliczu rozmaitych wartości, praktyk czy wręcz instytucjonalnych rozwiązań o charakterze ponadlokalnym, mających jednak wpływ także na kwestie lokalne. Takie inicjatywy mają jednak szanse powodzenia tylko wtedy, kiedy są w stanie wykorzystywać rozmaite zasoby, obecne zarówno na poziomie lokalnym, jak i ponadlokalnym. Dodatkowym czynnikiem wpływającym na skomplikowanie całego obrazu jest rola i znaczenie inicjatyw, organizacji i instytucji związanych z produkcją rolną, posiadającą silne zakorzenienie $\mathrm{w}$ globalnych procesach ekonomicznych. W każdym razie trzeba podkreślić, że trudno zaobserwować jakąś linearną ewolucję relacji władzy i współrządzenia na obszarach wiejskich. Właściwe ujęcie analityczne tej sytuacji to raczej złożony obraz tych relacji.

W rozdziale zawierającym konkluzje do omawianego tomu dwaj wspomniani już wcześniej redaktorzy, tj. Shucksmith i Brown próbują naszkicować zakres tematyczny dalszych badań. W pierwszej części swojego końcowego szkicu nawiązują do wprowadzenia, podkreślając, że szereg opracowań zawartych w redagowanym przez nich tomie tak czy inaczej odnosi się do zagadnień powiązań różnych miejsc, nierówności, finansowego kryzysu państwa czy też obszarów wiejskich jako miejsc opozycji wobec reprodukcji neoliberalnych praktyk. Interesujące stają się rozważania dotyczące natury „międzynarodowej” perspektywy. Co prawda - jak zaznaczają 
redaktorzy - omawiany tom skupiony jest na problemach społeczeństw Globalnej Północy, niemniej pokazuje, jak ta Globalna Północ jest pełna złożoności i różnorodności. Istotnym elementem prowadzonych rozważań jest także zarysowanie nowych tematów. Redaktorzy wskazują w tym kontekście na rosnącą nieadekwatność dychotomii wiejsko-miejskiej (rural/urban dichotomy), podkreślając ważną kwestię badania relacji oraz wzajemnych odniesień społeczności czy podmiotów wiązanych tradycyjnie z wiejskością oraz miejskością. Okazuje się także, że sytuacja ludności i społeczności wiejskich staje się coraz bardziej niepewna (precarious), w dużej mierze z uwagi na rozmaite efekty neoliberalnej polityki i globalizacji. Co jednak zadziwiające, to fakt, że wraz z obserwowanymi przemianami nie możemy jednoznacznie twierdzić o nasilającej się separacji natury (przyrody) i społeczeństwa. Wręcz przeciwnie, co podkreślają redaktorzy tomu, przyroda i społeczeństwo są ze sobą nierozerwalnie powiązane. Migracje także stają się coraz bardziej istotnym elementem współczesnych przeobrażeń społecznych. Z jednej strony obserwować można wyludnianie się różnych obszarów wiejskich, z drugiej zaś napływ ludności, zwłaszcza na obszary wiejskie leżące w pobliżu wielkich miast. Trzeba także pamiętać o migracjach międzynarodowych, spowodowanych nie tylko naturalnymi procesami urbanizacji, ale też innymi okolicznościami, takimi jak lokalne wojny czy konflikty powodujące nasilenie się procesów uchodźstwa. Wreszcie na zakończenie redaktorzy podnoszą ponownie, zarysowany na wstępie, problem analiz skupionych wokół określonych problemów społecznych. Stawia to istotne pytania dotyczące roli i znaczenia badań naukowych w odniesieniu do opracowywanych i wdrażanych polityk, wiarygodności samego środowiska naukowego i rozprzestrzenianych przez nie opinii, wreszcie przekonywania opinii publicznej do tez głoszonych w oparciu o dowody zgromadzone w badaniach naukowych. Podkreśla się w tym kontekście wzrastającą rolę badań stosowanych i jednocześnie konieczność wzmocnienia relacji i powiązań pomiędzy badaczami oraz twórcami polityki.

\section{Zakończenie}

Obydwa omówione w tym eseju opracowania liczą niemal 1200 stron tekstu, przypisów oraz indeksów. Tworzy je w sumie 90 rozdziałów, z których każdy ma charakter osobnego artykułu, a twórcami jest dobrze ponad 100 autorek i autorów. Można je zatem - w moim przekonaniu - traktować jako swoisty portret współczesnej socjologii wsi. Obydwa opracowania (jeśli chodzi o moment publikacji) dzieli równo dziesięć lat. Obydwa w mniejszym czy większym stopniu, mimo ambicji (zawartej także w sposobie sformułowania tytułu, zwłaszcza tego bardziej współczesnego opracowania) dotyczących ich międzynarodowego charakteru, skupiają się przede wszystkim na problemach obszarów wiejskich tzw. Globalnej Północy, co oznacza przede wszystkim problemy wiejskie w Wielkiej Brytanii i Stanach Zjednoczonych, w mniejszym stopniu także w Kanadzie, Australii, Nowej Zelandii i Europie kontynentalnej, 
a już zupełnie marginalnie $\mathrm{w}$ innych częściach świata. Zasadnicze jednak różnice między nimi są dwie. O ile w pierwszym (z 2006 roku) z omawianych opracowań ważna jest kwestia perspektyw analityczno-teoretycznych (tzw. teoretycznych koordynatów), o tyle w drugim (z roku 2016) bardziej istotna jest kwestia rozmaitych bardziej szczegółowych kwestii, którym poświęcone są odpowiednie fragmenty analiz. Ponadto w pierwszym opracowaniu brakuje wyraźnego wstępu i zakończenia, co świadczyć może o większej autonomii poszczególnych podejmowanych w analizach kwestii. Natomiast w opracowaniu drugim obszerna ilość szczegółowych analiz wymusza sformułowanie jakichś ogólniejszych uwag ze strony redaktorów tomu. Świadczyć to może - w moim przekonaniu - o tym, że w ciągu dziesięciu lat socjologia wsi (czy raczej studiów nad obszarami wiejskimi) doświadczyła efektów inter- i transdyscyplinarności, co spowodowało wymieszanie rozmaitych wątków i perspektyw analiz, które nie dają się łatwo wyodrębnić w bardziej autonomiczne perspektywy analizy obszarów wiejskich. Obydwa opracowania świadczą jednak o swoistej strukturze międzynarodowego dyskursu naukowego dotyczącego obszarów wiejskich, w którym problemy doświadczane przede wszystkim w najbardziej zaawansowanych rozwojowo krajach traktowane są jako uniwersalne zagadnienia.

\title{
Bibliografia
}

Cloke P., Marsden T., Mooney P. (eds.) (2006). Handbook of Rural Studies. SAGE Publications, London-Thousand Oaks-New Delhi, ss. 511.

Shucksmith M., Brown D. (eds.) (2016). Routledge International Handbook of Rural Studies. Routledge (Taylor \& Francis Group), London, New York, ss. 697.

\section{Krzysztof Gorlach}

\section{SELF-PORTRAIT OF CONTEMPORARY RURAL SOCIOLOGY. SOME THOUGHTS BASED ON TWO HANDBOOKS}

\begin{abstract}
In this analysis, based on the content of two handbooks, some considerations concerning ways and areas of rural studies have been considered. Both handbooks have been designed as kinds of global analyses. In fact, both of them have been focused on the so-called Global North issues, with a few exemptions concerning Eastern Europe and Latin America. At the same time, there are some differences between both handbooks. While in the first one (published in 2006) some leading theoretical coordinates seem to be of primary importance, in the second one (published in 2016) some more peculiar analyses seem to dominate the whole discourse. Moreover, in the first handbook, the lack of major introduction and conclusion have been quite visible. It means that considerations focused on particular theoretical coordinates have been more autonomous. Quite contrary, in the second handbook, a whole number of quite specific analyses has required some significant remarks prepared by the editors. These differences have led to the conclusion that in the last 10 years rural studies have experienced some important impacts of inter- as well as trans-disciplinarity leading to combinations of various themes and analyses not easily forming more general and autonomous perspectives on rural issues.
\end{abstract}

Key words: rural sociology, rural areas, handbooks, Global North, interdisciplinarity, transdisciplinarity. 